\title{
Clínica do trabalho e experiência de formação com trabalhadoras de escolas públicas no Brasil
}

\author{
Maristela França ${ }^{\mathrm{I}}$, Milton Athayde ${ }^{\mathrm{II}}$, Hélder Muniz ${ }^{\mathrm{III}}$, \\ Mary Yale Neves ${ }^{\text {III }}$ e Jussara Brito ${ }^{\text {IV }}$ \\ ${ }^{\text {I }}$ Universidade Federal do Estado do Rio de Janeiro (Rio de Janeiro, RJ) \\ II Universidade Estadual do Rio de Janeiro (Rio de Janeiro, RJ) \\ III Universidade Federal Fluminense (Niterói, RJ)

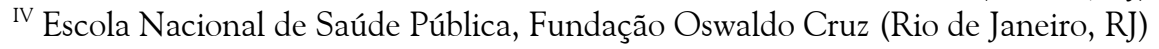

\begin{abstract}
O estudo discute o modo como o Programa de Formação em Saúde, Gênero e Trabalho nas Escolas concebe e recorre ao dispositivo denominado Comunidade Ampliada de Pesquisa (CAP), na tentativa de colaborar para a sinergia entre os polos que configuram a perspectiva ergológica (DD3P), que tem por meta o compreender $\leftrightarrow$ transformar em parceria - pesquisadores profissionais e pesquisadores práticos (protagonistas do trabalho em análise, militantes sindicais etc.) - por meio de "encontros sobre o trabalho" que combinam formação, pesquisa e intervenção. $\mathrm{O}$ dispositivo CAP visa colocar o trabalho em situação clínica a partir de um método de alternância - curso/exercícios de análise realizados pelos trabalhadores /encontros sobre o trabalho. O enquadre clínico instaura e desenvolve um espaço dialógico particular de confronto de saberes e experiências, fazendo circular na CAP, de forma fecunda, uma comunidade dialógica voltada a analisar o trabalho individual e coletivo. A experiência desenvolvida nas escolas é apresentada em sua potência de clínica do trabalho a partir de algumas sequências de diálogos pelo que elas constituem de dinâmicas interlocutivas particulares e pelo que revelam sobre os esforços dos sujeitos para criar instrumentos de ação sobre si mesmos e os outros.
\end{abstract}

Palavras-chave: Clínica do trabalho, Perspectiva ergológica, Comunidade ampliada de pesquisa, Dispositivo dialógico, Desenvolvimento.

Clinic of work and training experience with workers from public schools in Brazil

This study discusses how the Training Program in Health, Gender and Work in Schools conceives and uses the device called Extended Community Research (ECR), in an attempt to collaborate with the synergy between the poles underpinning the ergological perspective (DD3P), which aims to understand $\leftrightarrow$ transform in a partnership professional researchers and practical researchers (those that exercise practical work in analyses, trade unionists etc.) - through "work meetings" that combine research, intervention and training. The ECR device seeks to transform the work in school into clinical situations based on a method of alternation - course/analysis in schools/work meetings. The clinical setting establishes and develops a particular dialogic space of confrontation of knowledge and experiences, helping to circulate a fruitful community dialogue focused on analyzing the individual and the collective work. The experience developed in schools is presented as a clinical work from several series of dialogues so that they constitute specific dynamics which reveal the efforts of individuals to create tools of action to share between themselves and others.

Keywords: Clinic of work, Ergological perspective, Extended community research, Dialogical device, Development.

\section{Introdução}

$\mathrm{O}$ Colóquio sobre a Clínica da Atividade ${ }^{1}$ - do qual este artigo é um desdobramento - teve a finalidade de promover a divulgação, integração e dinâmica do trabalho de discussão crítica em grupo na comunidade científica pertinente. A proposta deste texto é apresentar ao debate reflexões teóricas e clínicas suscitadas pela experiência de desenvolvimento do Programa de Formação em Saúde, Gênero e Trabalho nas escolas realizado há mais de dez anos no estado do Rio de Janeiro e no município de João Pessoa, PB (Brito, Athayde \& Neves, 2003;

1 Realizado no Brasil, em São João del-Rei, MG, em outubro de 2010. 
Brito \& Athayde, 2003; Neves et al., 2007; Silva, Brito, Neves \& Athayde, 2009). ${ }^{2}$ Pretende-se também abrir o diálogo com aqueles que, especialmente em Psicologia do trabalho \& organizacional, estão particularmente preocupados com o aporte teórico, metodológico e técnico necessário para compreender $\leftrightarrow$ transformar situações de trabalho tão difíceis como as que se encontram na rede pública de ensino.

A linhagem da psicologia ergonômica e da ergonomia da etividade francofônica (para quem a exigência de respeito à saúde sempre foi um determinante destacado), desde os anos 1950, já sinalizava a importância das relações entre análise do trabalho e formação (Ombredane \& Faverge, 1955). Nos anos 1970, a questão da formação já apresentava nesse campo um perfil consistente, com destaque para figuras como Catherine Teiger e Antoine Laville. Essa modalidade de "formação pela e para a ação" (Lacomblez, 1995; Teiger \& Laville, 1991) propõe que a aprendizagem da análise do trabalho desenvolva simultaneamente a tomada de consciência e confiança no engajamento da ação. Por um lado, trata-se de reconstituir - rigorosamente e com detalhes, incorporando nesse processo os protagonistas da atividade (especialmente via verbalização e formas de autoconfrontação) - como se realizam efetivamente as tarefas, para além do prescrito e do observável, tudo aquilo que é mobilizado no curso da atividade, mas não se concretiza comportamentalmente. Por outro lado, a formação se torna meio de ação ergonômica transformadora, posto que procede de uma mudança de ponto de vista, de uma abertura perceptual e conceitual. Assim, a consistência da mudança encontra-se tanto na fecundidade das análises efetuadas, quanto na compreensão e confiança dos trabalhadores engajados e corresponsáveis pelo empreendimento. Não se trata, é claro, de uma fórmula de conscientização pedagogizante, mas de mútua aprendizagem (envolvendo a necessária humildade epistemológica, dada a cultura/incultura recíprocas, assim como o desconforto intelectual daí emergente), inclusive por parte dos profissionais da ciência envolvidos (Schwartz, 2010).

O trabalho na rede pública de ensino básico no Brasil vem sendo alvo de diversas críticas. As que encontram maior divulgação midiática são aquelas relacionadas aos baixos resultados obtidos pelos alunos nos exames nacionais e internacionais de avaliação, ou seja, que captam o problema enquanto resultado de um teste. Constatado o lamentável quadro, propostas são apresentadas tendo como foco o fracasso do desempenho escolar dos estudantes, diagnosticando sua origem principalmente em erro de transmissão, sob a alegação de uma falta de qualificação, competência e compromisso dos professores em lidar com os conteúdos que teriam sido prescritos. ${ }^{3}$ Segundo essa lógica, frequentemente a escola é vista e criticada apenas tendo como objeto uma visão centrada na relação professor-aluno. Encontra-se aqui, sobretudo, uma visão redutora da complexidade dos processos educativos e de ensinoaprendizagem, como se se tratasse de uma simples troca de informações, transportadas de uma fonte a um receptor-depositário. Trata-se, na verdade, de uma "visão bancária da educação", como designava Paulo Freire (1987), que não apreende a escola como espaço de um dado processo produtivo, ${ }^{4}$ em que transcorre um processo de trabalho, atravessado por relações sociais. Ou seja, ao considerar o que acontece na escola (como locus produtivo) é incontornável compreender o trabalho que aí se processa, o conjunto de elementos que o compõem, especialmente a atividade humana (que dá vida aos outros elementos ou os desenvolvem).

Nesse sentido, uma questão importante diz respeito à defasagem sempre existente entre o trabalho prescrito e o trabalho real, evidenciada pela ergonomia da atividade - campo do conhecimento que desde o segundo pós-guerra já apontava a necessidade de adaptar o trabalho

2 Posteriormente, outras experiências de pesquisa-intervenção-formação, com essa mesma perspectiva, desenvolveram-se em outras regiões do país, sendo coordenadas por outras equipes. São exemplos, as realizadas nos estados do Espírito Santo, do Tocantins e do Amazonas.

3 Lembramos que o conceito de tarefa prescrita, avançado pela ergonomia da atividade, remete não só a conteúdos e modos operatórios, compreendendo também explicitação das condições necessárias para seu exercício.

4 Aqueles resultados que registram o fracasso dos estudantes podem ser efeito da produtividade da escola. Como dizia Frigoto (2001) acerca da escola pública no Brasil, trata-se da "produtividade da escola improdutiva". 
às pessoas, invertendo e revolucionando a lógica taylorista predominante de adequar os homens ao trabalho (Faverge et al., 1958; Guérin et al., 2001). O trabalhar envolve uma dimensão sempre enigmática e simbólica, em que a atividade possui um volume de negociações - cognitivas, afetivas e sociais - que excedem o que é diretamente observável e mensurável (Dejours, 2004; Schwartz, 2000). O esforço aqui é o entendimento do trabalho como uma relação social que não é somente heterodeterminada, mas produto de homens e mulheres concretos que mobilizam a si e às redes sociais pertinentes para desenvolver suas atividades. Assim, o trabalho, para que se o compreenda $\leftrightarrow$ transforme, tem que ser analisado, em sua complexidade, como um campo de contradições e determinações múltiplas, de (in)culturas, de valores e de relações sociais de produção com trajetórias diversas. Em síntese, um campo mediado pela história singular e social desses agentes (Schwartz, 2010).

Neste texto, pretende-se apresentar o trabalho realizado no referido Programa de Formação (no estado do Rio de Janeiro) em sua potência enquanto clínica do trabalho e explorar o principal ponto em que nossa prática faz interseção com a clínica da atividade (Clot, 2010). Esse ponto em comum encontra-se no Modelo Operário Italiano (MOI) de produção de conhecimento e de luta pela saúde (Oddone, Re \& Brianti, 1981) que propõe uma nova forma de desenvolvimento para a Psicologia do Trabalho, um outro dispositivo clínico, em que os trabalhadores interessados são convidados a participarem da (co)análise do seu próprio trabalho, entendendo que a discussão sobre sua experiência pode ser um meio para seu desenvolvimento e transformação, através da ampliação da potência e do poder de ação dos coletivos sobre o seu trabalho e sobre cada um dos seus protagonistas. Assim, o Programa de Formação explora um método que opera, após um curso inicial, com exercícios de coanálise do trabalho, do ponto de vista da atividade. Pretende-se que já nos exercícios de formação criemse as condições para a emergência e transmissão da experiência, fazendo da repetição um meio para a variação.

Conforme se validou com as descobertas dessa linhagem da ergonomia da atividade - $\mathrm{O}$ paradigma da "formação dos atores na e pela análise do trabalho, para e pela ação" (Teiger \& Daniellou, 1987; Teiger \& Lacomblez, 2013, 2007) -, entendeu-se que no interior do Programa de Pesquisas que vinha se desenvolvendo seria necessário construir um Programa de Form ação, fazendo uso do dispositivo que desde então se denominou Comunidade Ampliada de Pesquisa (CAP) (Brito \& Athayde, 2003; Silva et al., 2009). Com a CAP - uma configuração do Dispositivo Dinâmico de Três Polos (DD3P) (Schwartz, 2000) -, busca-se colaborar para a sinergia entre os três polos que conformam a perspectiva ergológica de produção de conhecimento (Schwartz, 2010). Em última instância, tem-se por meta "compreender $\leftrightarrow$ transformar as situações de trabalho em parceria" - pesquisadores profissionais e pesquisadores práticos (protagonistas do trabalho na escola e, nesse caso específico, também dirigentes e militantes sindicais) - por intermédio de "Encontros sobre o Trabalho" (Durrive, 2010) que combinam formação, pesquisa e intervenção.

O dispositivo CAP visa colocar o trabalho em escolas em um enquadre clínico 5 a partir de um método de alternância - curso/exercícios de análise nas escolas realizados pelas trabalhadoras 6 encontros sobre o trabalho/exercícios de análise nas escolas - que instaura e desenvolve um espaço de debate crítico e criativo entre o universo dos conceitos e o da experiência. A CAP é atravessada por uma comunidade dialógica (França, 2007), em particular a que almeja desenvolver a capacidade de análise sobre as relações entre vida, saúde e trabalho.

5 Conforme Figueiredo \& Athayde (2004, p. 245), entende-se aqui por clínica não uma prática de tratamento, mas “um regime de produção de conhecimento pertinente ao caráter sempre enigmático e singular do trabalho. Um regime de coprodução, engajando em um espaço de colaboração os meios (milieux) de trabalho/racionalidade da ação e o meio científico/racionalidade científica". Uma abordagem clínica do trabalho seria "uma intervenção na produção e afirmação de um desvio, na criação de novos territórios existenciais".

6 Desde já, esclarecemos que independentemente da regra gramatical (que se constitui ela mesma em uma produção social), estaremos nos referindo aos trabalhadores e trabalhadoras de escolas que compõem o ensino fundamental sempre no feminino - as trabalhadoras - devido ao fato de sua composição ser majoritariamente de mulheres. Dessa forma, procuramos tornar visível a divisão sexual do trabalho. 
Para tanto, busca-se colocar em funcionamento um dispositivo dialógico de (co)análise, de modo que os profissionais de educação ${ }^{7}$ tornam-se responsáveis por construir um ponto de vista sobre o que fazem, e como fazem. Nos diálogos que se sucedem na CAP, as trabalhadoras estabelecem laços da cultura histórica compartilhada nas escolas e nos ciclos de encontros sobre o trabalho, operando "sistemas de referências" (Geraldi, 2003), que são modos de ver o trabalho a partir da experiência.

O trabalho de construção de sentido nos encontros sobre o trabalho diz respeito a essa produção histórica e social de sistemas de referências em relação aos quais os recursos expressivos se tornam significativos, ou não, para as trabalhadoras de escolas e para os pesquisadores-especialistas. Citando Franchi (1977), Geraldi (2003) afirma que

a língua enquanto sistema simbólico torna-se significativa por remeter a um sistema de referências, produzido nas relações interativas que, por seu turno, situam-se numa determinada formação social e são por esta marcadas. Daí compreender a linguagem como trabalho constitutivo dos sistemas de referência e dos sujeitos cujas consciências se formam precisamente pelo conjunto de categorias que vão incorporando, enquanto signos, nos processos interlocutivos de que participam (p. 14).

O dispositivo desencadeia, por intermédio do ciclo dialógico que constitui o Programa de Formação, um processo interlocutivo no qual o trabalho dos sujeitos com a linguagem e sobre a linguagem, agenciando recursos expressivos, os insere na historicidade da experiênciatrabalho.

Parte-se de dois pressupostos de base. Os diálogos nos encontros sobre o trabalho são enunciados e, como tal, são um elo na cadeia dialógica do funcionamento do grande diálogo (Bakhtin, 1988) no qual a linguagem se constitui. Ao mesmo tempo, tais encontros são acontecimentos discursivos nos quais os participantes trabalham na construção de sentido no "aqui e agora" de cada enunciação. Sendo única e não reiterável, cada enunciação tem um sentido também definido e único: o tema. Propriedade da enunciação como um todo, é preciso compreender o tema em sua relação com o significado (Bakhtin, 1988). A significação se funda na semanticidade da língua, na historicidade de sua presença em interações anteriores e nos sentidos que lhes foram sendo atribuídos (Geraldi, 2003). O tema se realiza no ato interlocutivo da significação por meio do trabalho dos sujeitos com os signos. O trabalho linguístico está sempre produzindo uma sistematização aberta, "consequência do equilíbrio de duas exigências opostas: uma tendência à diferenciação, observável a cada uso da expressão, e uma tendência à repetição" (Geraldi, 2003, p. 12). Não é como se qualquer expressão pudesse significar qualquer coisa.

O trabalho de determinação do tema nos encontros sobre o trabalho desperta particular interesse de analistas do trabalho (não só psicólogos e linguistas) que encontram aí um terreno privilegiado para investigar nem tanto o plano do sentido, mas o dos instrumentos psicológicos de ação (Clot, 2010; Papegnies, 2006). O que é mais relevante para o acontecimento da clínica é como age o sujeito com o dispositivo dialógico instaurado para sustentar seus esforços para criar instrumentos de ação sobre si mesmo e sobre os outros.

Antes de seguir com os fundamentos teóricos e clínicos do Programa de Formação será preciso, ainda que brevemente, indicar as bases epistemológicas com as quais nossa rede de pesquisadores opera nesse Programa.

7 Usa-se nesse momento a expressão escolhida pelo movimento sindical dos trabalhadores de escola para designar o conjunto de segmentos que fazem acontecer o trabalho nas escolas, visando marcar a profissionalidade educativa de todos, inclusive aqueles a quem a administração categoriza como "funcionários de apoio". 


\section{Um trabalho em rede e a perspectiva ergológica}

Entendemos que, para orientar os diálogos sinérgicos sobre o trabalho - seja entre diferentes disciplinas e no interior de cada uma delas, seja entre os saberes da ciência e da prática -, a ergologia vem confirmando uma potência que tem se mostrado imprescindível, em especial o dispositivo dinâmico de três polos - DD3P - que conjuga diferentes forças em relação magnética (Schwartz, 2000, 2010).

O primeiro polo é o das disciplinas científicas, dos saberes não investidos, em desaderência, que tenham como objeto de estudo o trabalho. A psicologia, as ciências da linguagem, da saúde, da engenharia e da gestão, as ciências sociais e a ergonomia (uma disciplina estranha, híbrida) ${ }^{8}$ contribuem na compreensão do trabalho e das atividades e podem ser convocadas pelas forças presentes nas situações de trabalho.

No segundo polo, estão as forças de convocação e validação, assim como os saberes investidos na atividade - aquelas que estão na origem das demandas e na transformação das situações em que estão diretamente protagonizando, em cada contexto histórico. Nesse polo podem estar presentes, por exemplo, o movimento sindical (que, em nosso caso, formulou a demanda inicial no Rio de Janeiro), o aparelho de Estado (Secretarias de Educação, Saúde, Trabalho, Administração), a direção de uma escola específica, as trabalhadoras de uma dada escola, de um município ou estado, ou qualquer outra força social que se revele capaz de convocar pesquisadores profissionais a se implicarem em sua demanda. Se no polo precedente encontram-se os saberes conceituais e científicos, aqui estão os saberes da experiência, investidos na atividade, em aderência com as situações concretas. Essas forças convocam os profissionais de pesquisa para colaborarem, configurando-se um debate (sempre desconfortável, dadas as culturas e inculturas recíprocas) entre a experiência e os conceitos, exigindo humildade epistêmica. Mas encontramos aí a expectativa de um círculo virtuoso, pois essa convocação envolve também um compromisso de retrabalho, inclusive no interior das disciplinas, validando o conhecimento então produzido no debate, com vista a uma nova construção.

O terceiro polo é o da exigência ética e epistemológica no campo da produção de conhecimento. A compreensão da atividade como força renormatizadora (considerando o necessário exercício da capacidade normativa) e ressingularizante - como a que diz respeito a quais saberes e valores "universais" podem ser retrabalhados naquela situação específica, gerando a produção de novos saberes e valores - exige uma tomada de posição ética e epistemológica, precedendo negociações e acordos. A discussão sobre a relação entre os saberes (científico e da experiência) é extremamente importante, incontornável para dar conta da meta estratégica de compreender $\leftrightarrow$ transformar positivamente os mundos do trabalho.

\section{A ciência linguística convocada pelo Programa de Formação}

Apresenta-se agora, sumariamente, o campo das ciências em que a linguagem se constrói como objeto teórico-metodológico no Programa de Formação. A vertente da linguística convocada pelas forças presentes nas situações de encontro sobre o trabalho realizadas situa-se entre as abordagens que no Brasil constituem a Linguística Aplicada (LA) (Celani, 1992; Faraco, 2001; Moita Lopes, 1996), justamente pelo interesse em pesquisar e desenvolver instrumentos teórico-metodológicos que, no campo dos usos da linguagem, ajudam a tratar questões que interpelam o cenário social do seu tempo. O princípio de

8 Schwartz (2004) ousa propor investigar em que medida, talvez, ela seja hoje uma propedêutica à epistemologia. 
contemporaneidade que enquadra essa LA convoca o pesquisador de linguagem a se engajar nas problemáticas de seu tempo.

Se por um lado esse princípio parece dar um tom homogêneo à LA, por outro, sua prática não se constitui, de modo algum, consenso em relação ao objeto que privilegia ou ao paradigma a que se recorre para abordá-lo. A propósito, Celani (1992) e Moita Lopes (1996) apresentaram alguns dos motivos pelos quais, em lugar de uma única, o correto é falar nas várias correntes em LA. Numa primeira corrente, os autores situaram aqueles que entendem LA como a aplicação de teoria linguística para resolver problemas de ensino de língua, por exemplo. Numa segunda, posicionaram linguistas cuja abordagem se desenvolve nos limites de uma única disciplina teórica (da análise da conversação, por exemplo). Em uma terceira corrente, entende-se LA como sendo de natureza interdisciplinar e mediadora. Os pesquisadores que com ela se alinham têm de buscar subsídios para suas investigações em outras disciplinas (Moita Lopes, 1996).No Brasil, as questões da Educação foram sempre área de grande mobilização acadêmica, interligando várias disciplinas. Por essa razão, era de se esperar a forte corrente que se formou (nos anos 1980 e durante a década de 1990) em LA focada na situação de aprendizagem. Dialogando, principalmente, com a abordagem da Psicologia Histórico-Cultural de Vygotsky, pesquisas foram e continuam sendo feitas por linguistas, tendo como objeto a função da interação verbal nos processos de aprendizagem (Cavalcanti \& Moita Lopes, 1991; Santos, 1994). Estudando as funções psicológicas no desenvolvimento da criança, Vygotsky (1991) observa que todas elas "aparecem duas vezes; primeiro, no nível social, e, depois, no nível individual; primeiro, entre pessoas (interpsicológica), e, depois, no interior da criança (intrapsicológica)" (p. 75). A interação da criança com outras pessoas e com o meio que as cerca, observa ainda Vygotsky, tem um papel essencial: ela a habilita a operar com objetos e situações que não estão presentes na situação face a face, de modo a extrapolar os limites da experiência direta. A palavra, diz Luria, ${ }^{9}$ "duplica o mundo" (1987, p. 32). A formação do plano intrapsicológico concretiza-se principalmente através da mediação das ações da criança pela palavra. Com a palavra, de acordo ainda com Vygotsky, se inicia o processo de autorregulação de conduta, enraizado sempre no plano social. Apesar da importância dessa corrente histórico-cultural nos caminhos que tomou a LA no Brasil, as pesquisas realizadas não consideraram dois aspectos importantes: seja o fato de os contextos de interação verbal na sala de aula serem, antes de tudo, parte constitutiva das atividades de trabalho na escola; seja de o campo do trabalho poder ser pensado também como um lugar de desenvolvimento, inclusive, dos adultos, em que se aprende e compartilha.

A abertura dessa terceira vertente de LA para o estudo de situações de trabalho ocorreu na década de 1990 e, desde então, só vem ampliando e aprofundando seus campos de ação como uma forma de o linguista colocar sua prática em sincronia com as questões que interrogam os mundos do trabalho de seu tempo (Feitosa, 1996; Souza \& Silva, 2002; Machado, 2004). No caso específico de uma das vertentes do grupo Ateliê Linguagem e Trabalho $^{10}$ (PUC-SP), nas pesquisas em LA que vêm sendo conduzidas, o ponto de vista da atividade tem supremacia em relação a qualquer outro. Busca-se estudar o discurso e as práticas linguageiras compondo com diferentes campos que focalizam o trabalho para os quais esse ponto de vista também é fundamental. ${ }^{11}$ No Programa de Formação, no processo sinérgico entre disciplinas convocado pelo dispositivo DD3P, a LA se associa à psicologia do trabalho \& organizacional por intermédio de uma prática voltada para a fabricação de ferramentas com vista a colocar o trabalho no trabalho da clínica. Trata-se de um dispositivo dialógico, instrumento psicológico de agir sobre si e sobre o outro (Clot, 2010). Sob o ponto de vista

9 Outro componente da chamada Troica, com Leontiv e Vygotsky.

10 Vertente a que está associada França, linguista que colabora com o Programa de Formação.

11 Trata-se de um amplo conjunto de pesquisas, entre as quais: Feitosa (1996), Souza e Silva (2002), Sant'Anna (2004), França (2007), Vieira (2002), Di Fanti (2004), Harrison (2006), Daher e Sant'Anna (2010) e Lima (2010). 
teórico, esse enquadramento concebe a linguagem sob a ótica da linguística dialógica (Faïta, 2005; França, 2007; François, 1998), incorporando os aportes da pragmática-discursiva (Amossy, 2006; ${ }^{12}$ Silva, 2010), de modo a abordar a ação que se faz com e sobre a linguagem (Geraldi, 2003) no processo de construção e de desenvolvimento das relações dialógicas (Bakhtin, 1988; Faita, 2005). Sob o ponto de vista ético, trata-se de uma Linguística (Rajagopalan, 2003) voltada para a prática de um ofício que visa a transformação, porém, entendendo que a transformação das situações de trabalho não funciona se delegada a um especialista externo ao trabalho. A função do especialista é a de usar seu saber para fornecer meios aos protagonistas do trabalho. Só tais agentes são capazes de produzir transformação e a ela dar consistência efetiva. Extraímos ensinamentos dos estudos de Faïta, principalmente os desenvolvidos sobre a situação de trabalho de condutores de trem da empresa pública francesa SNCF $(1989,1992,1996)$, que evidenciaram aquilo que Oddone et al. (1981) verificaram em análise realizada no final da década de 1960 e estabeleceram como um de seus princípios: o da "não delegação" a terceiros da responsabilidade de solução para problemas vividos coletivamente no trabalho.

\section{Estatuto da atividade de formação em clínica do trabalho}

Clot (2010) extrai os principais ensinamentos da experiência do MOI fazendo uso do dispositivo "comunidade científica ampliada" - CCA (Oddone et al., 1981), dando destaque para o modo como se conseguiu ir além da simples denúncia das condições de trabalho, canalizando esforços para reforçar a luta que os trabalhadores já envidavam para a transformação do seu trabalho, considerando os problemas de saúde então emergentes. Oddone e seus parceiros exercitaram concretamente uma abordagem clínica do trabalho que serviu de instrumento para a ampliação da potência e do poder de ação dos coletivos de trabalho sobre o seu trabalho e sobre cada um de seus protagonistas. Propuseram uma nova forma de desenvolvimento para a psicologia de trabalho, ${ }^{13}$ um outro dispositivo clínico, no qual os trabalhadores interessados em compreender $\leftrightarrow$ transformar suas situações de trabalho são convidados a participar da análise do seu trabalho, considerando que a discussão da sua experiência pode ser um meio de transformação da mesma.

Assim, na experimentação do MOI, tratava-se de exercícios que permitissem uma modalidade de transmissão da experiência que fizesse da repetição um meio para a variação. Como diz Clot (2010):

A transmissão da experiência, ao realizar-se efetivamente, equivale sempre a um desenvolvimento dessa experiência. Reconhecê-la é implicá-la em uma história que a modifica. E torná-la disponível para uma história diferente daquela de que ela é oriunda (p. 86).

Oddone et al. (1981) demonstram que os trabalhadores não agem sozinhos, existe uma ligação entre eles: a experiência-trabalho em comum (como "grupos homogêneos"), que serve de apoio para os seus planos de ação organizada (e autônoma, com base no princípio da "não delegação"). Ao mesmo tempo, em retorno, sua ação auxilia na (re)construção dessa experiência. Clot e Faïta (2000) vão desenvolver o conceito bakhtiniano de gênero de discurso enquanto gênero profissional para abordar "esses meios de agir; recursos de que se pode dispor, assim como obrigações a cumprir para fazer valer nossas intenções no intercâmbio com os

12 A autora designa seu trabalho como a "argumentação no discurso". Mas, ao fazê-lo, fornece um panorama conceitual que, ao nosso ver, pode ser lido como uma síntese do que seria o campo da pragmática-discursiva.

13 Aqui se mantém a denominação usada por Oddone et al., embora hoje a opção dos autores do artigo seja Psicologia do Trabalho E) Organizacional. 
outros e no uso dos objetos" (Clot, 2010). Porém, os autores entendem que esse gênero profissional deve ser constantemente renovado para se manter vivo: a energia que o vitaliza são as estilizações que vão ser acionadas pelos trabalhadores no curso de suas atividades.

Assim, uma orientação importante para a prática de uma clínica do trabalho na linha da clínica da atividade é propiciar um espaço onde essas estilizações circulem e sejam debatidas. Na situação atual, a precarização das condições e formas de organização de trabalho nas escolas públicas dificulta muito o encontro entre os que ali atuam, instituindo-se uma aceleração que coloca impedimentos para os diferentes segmentos de profissionais de educação poderem parar para conversar com os outros (de qualquer segmento) sobre como está sua situação de trabalho, como estão trabalhando etc. Nesse contexto, torna-se fundamental a construção de dispositivos que permitam a instauração e circulação de uma comunidade dialógica (França, 2007), para que a estilização não se perca no monólogo fastidioso e solitário de um trabalhador sem interlocutor e sem tempo, nem para discutir consigo mesmo, inviabilizando processos de produção de sentido.

A estratégia do Programa de Formação visa estabelecer encontros - inusitados, mas planejados e sistemáticos - entre trabalhadoras que quase nunca têm espaço nem tempo de se encontrar na escola, por diversas razões (Souza, 2009). Visa também gerar no meio um espaço de encontro onde o que parece óbvio, como uma simples transmissão de uma descrição de seu espaço de trabalho, de seus instrumentos e de sua relação com eles, pode se transformar em um meio para o seu desenvolvimento. Sim, pois a exigência de explicar, colocar em palavras para outros que não têm a mesma experiência de seu trabalho (seja uma colega de profissão, seja a de outro segmento profissional, seja um leigo, como o pesquisador profissional), detalhes que parecem insignificantes, encontra na interlocução com os outros, suas perguntas, seus questionamentos, uma mobilização para pensar de uma forma diferente sua própria experiência. É assim que, no programa, os relatos dos exercícios de estudo de campo, que às vezes começam como um "dever de casa", até mesmo como uma descrição meio monótona, de repente dão lugar a desvios, a variações, a conversas inesperadas sobre a vida no trabalho. É exatamente quando a atividade de falar sobre as atividades que compõem o próprio trabalho produz uma transformação na sua relação com esse trabalho e com seus colegas.

Nas escolas da rede pública, no Brasil, a herança cultural da lógica escravista persevera, trazendo em seu rastro obstáculos para o diálogo e a união de quem trabalha na escola. Por exemplo, no Programa de Pesquisas aqui em foco, Nunes (2000) enfatiza como uma divisão tipo "casa-grande e senzala", descrita por Gilberto Freyre (2006), se reproduz em muitas escolas, com as "merendeiras" 14 ficando isoladas na cozinha-senzala, sem ter acesso ao que acontece no espaço considerado nobre da escola, a "casa grande", onde o processo educativo e de ensino-aprendizagem ocorreria, exclusivamente operado pelos professores e professoras. A estratégia do Programa de Formação de colocar, lado a lado, trabalhadoras de diferentes segmentos profissionais favorece a construção de um espaço profícuo para o enfrentamento desses obstáculos instituídos. Além do mais, atividades como os estudos de campo têm sido realizadas de forma criteriosa e criativa pelas "merendeiras" e "serventes" (ou "auxiliares de serviço gerais"), ${ }^{15}$ trabalhadoras com formação escolar incompleta, que exploram esses estudos de campo como um meio desenvolvimental. Ou seja, encontramos, por exemplo, trabalhadoras semianalfabetas como as que mais se revelaram interessadas e capazes de ampliar a comunidade de pesquisa nas escolas em que trabalhavam (compensando suas dificuldades), potencializando seu estudo e colaborando especialmente para o êxito dos objetivos do Programa.

14 As aspas aqui sinalizam para uma crítica à designação que a administração pública vem dando ao trabalho de quem, em outros âmbitos, se designa por cozinheiras. Equívoco que a expressão no campo da Nutrição - "manipulador de alimentos" - não resolve, ao contrário.

$15 \mathrm{Na}$ verdade, como no caso das chamadas merendeiras, trata-se de trabalhadoras cujos serviços vão da higienização do meio a seu controle (como porteiros, vigias etc.). 
Brito e Athayde (2003) ressaltam que esse Programa de Formação apresenta como característica, portanto, o espaço e a disposição dos trabalhadores de dialogarem entre si e com os pesquisadores profissionais, buscando conhecer $\leftrightarrow$ transformar a dura realidade lamentavelmente presente nas escolas públicas. Isso pode parecer insuficiente e óbvio, mas quem convive com essa realidade sabe que a fragmentação dos coletivos, as triplas jornadas de trabalho das mulheres (geradas pelos salários insuficientes e pela divisão sexual do trabalho), o fardo da herança cultural da lógica escravocrata, entre muitos outros perversos fatores, são elementos que conspiram para tornar extremamente difícil a ação coletiva de compreender $\leftrightarrow$ transformar. Por isso são tão importantes os encontros de trabalhadores de diferentes segmentos profissionais que, ao ocorrerem, dão vida e conferem nobreza ao que fazem na escola, apesar das imensas dificuldades pelas quais de modo geral não são responsáveis. Entendemos, assim, que a criação e o desenvolvimento de diferentes configurações do paradigmático DD3P, como é o caso do dispositivo CAP, revela-se como uma urgência para quebrar imediatamente os "muros de Berlim" instituídos na rede pública escolar, um dos operadores da sua improdutividade socialmente produzida.

\section{O método no Programa de Formação: o dispositivo CAP como dispositivo dialógico}

O Programa está estruturado em forma de ciclos, em que, desde o primeiro, o objetivo é a formação de "multiplicadoras" (é importante que estas primeiras sejam trabalhadoras reconhecidas em sua liderança e autoridade no seio do movimento). Do segundo ciclo em diante, o enfoque está na formação de "multiplicadores de base" (demais militantes sindicais e trabalhadoras de escola em geral, contemplando os diferentes segmentos profissionais). A diferença do ciclo inaugural para os seguintes é que a partir do segundo ciclo as trabalhadoras designadas "multiplicadoras" participam ativamente de todo o processo de formação de outras colegas ("multiplicadoras de base"), enquanto no primeiro ciclo a equipe constituída pelos pesquisadores profissionais tem a responsabilidade de inaugurar o processo, formando as primeiras multiplicadoras.

Cada ciclo de formação contém duas etapas consecutivas. A primeira caracteriza-se como um curso, organizado com exposições de pesquisadores profissionais sobre temas escolhidos (fruto de pesquisas anteriormente realizadas), seguido de práticas em alguma medida inspiradas nos "círculos de cultura" de Paulo Freire (1987), leituras de textos sob o formato de perguntas e respostas previamente preparados em "Cadernos" e discussões em pequenos grupos, em seguida, no grupo que envolve todas as participantes. Nessa fase, começa-se a trabalhar de forma mais estrita o enquadre clínico. As discussões que partem dos textos e conceitos apresentados no curso levam, na sessão de confronto com a experiência, a uma dinâmica de controvérsias entre um "eu faço... diferente de você", constituindo uma relação intersubjetiva por intermédio da qual o trabalho é constituído tema de cada enunciação.

No final dessa primeira etapa, ocorre a escolha de focos de análise que guiarão (como temas geradores, na linguagem de Freire) a segunda etapa, configurando-se a alternância, já que as trabalhadoras retornarão às escolas para a realização de exercícios de estudo de campo e voltarão a se encontrar com as outras colegas e a equipe de formação nos encontros da CAP sobre o trabalho. Nesses encontros, as trabalhadoras (individualmente ou em duplas) trazem os relatórios de seus exercícios de estudo nas escolas para o debate com os demais. O conjunto de diálogos que serão a seguir contemplados neste artigo é proveniente de situações vivenciadas em dois encontros do tipo, realizados no Rio de Janeiro em um dos ciclos de formação de multiplicadoras, destinados a trabalhadoras da capital, realizado em 2008. 


\title{
O trabalho linguístico e as relações dialógicas
}

Para compreender a ação clínica, é essencial focalizar a dinâmica do trabalho linguístico constitutivo da linguagem e dos próprios sujeitos. Esse trabalho é especificado por Geraldi (2003) como sendo um movimento que acontece em dois níveis que se entrecruzam. O primeiro nível é lugar de "produção histórica e social de sistemas de referência em relação aos quais os recursos expressivos se tornam significativos" (p. 16). O segundo nível é o das operações discursivas que remetem aos sistemas de referência e permitem a intercompreensão, mesmo quando há "vagueza dos recursos expressivos utilizados" (Geraldi, 2003, p. 16). A partir desse ponto de vista, que concebe a linguagem como trabalho dos interlocutores, o sujeito nem é tomado como a fonte dos sentidos nem como aquele que é completamente assujeitado a uma estrutura preexistente. Entre esses dois extremos, entende-se que a subjetividade consiste em uma prática linguageira cotidiana de ações linguísticas que dão vida e forma às relações dialógicas. Como os sujeitos não são cristalizações imutáveis,

\begin{abstract}
os processos interlocutivos estão sempre a modificá-los ao modificar o conjunto de informações que cada um dispõe a propósito dos objetos e dos fatos do mundo; ao modificar as crenças pela incorporação de novas categorias e, até mesmo, ao modificar a linguagem com que falamos e representamos o mundo e as relações dos homens neste mundo (Geraldi, 2003, p. 28).
\end{abstract}

O exame da dinâmica desses processos representa um interesse teórico e clínico para o Programa de Form $\underline{a c ̧ a \tilde{o}}$, na medida em que permite captar a linguagem em movimento: as ações sobre a linguagem incidem sobre os recursos expressivos e podem provocar deslocamentos nos sistemas de referências que se entrecruzam, transformando o embate das relações interlocutivas, muitas vezes, em batalhas, verdadeiras disputas sobre os sentidos. Nesse movimento, o agenciamento dos temas dá pistas sobre a organização instrumental das atividades interlocutivas e coloca luz nos esforços dos sujeitos em criar instrumentos de ação sobre si mesmos e os outros.

\section{Contexto social e análise das relações dialógicas}

O contexto social das interações verbais analisadas neste artigo provém dos encontros entre profissionais de pesquisa e pesquisadores práticos que, dando continuidade a um dispositivo dialógico iniciado em etapas anteriores do Programa de Form $\underline{a c a} a$, organizaram um meio em que o processo interlocutivo em torno de tópicos pertinentes ao trabalho, de certo modo escolhidos previamente por intermédio de um exercício, coloca em relação o universo dos conceitos e o universo da experiência de trabalho. Na dinâmica de interlocução instaurada, as trabalhadoras se tornam demandantes "de uma espécie de autorreflexão dialógica com sua relação ao trabalho como centro do saber solicitado" (Scheller, 2003, p. 62).

São analisadas a seguir duas sequências de diálogos, retiradas dos referidos encontros, tanto pelo que elas constituem de processos interlocutivos diferentes, quanto pelo que essa diferença pode manifestar dos propósitos teóricos e clínicos do Programa de Formaçãoo.

No encontro do qual se extraiu a primeira sequência, ocorreram cinco seções de retorno dos exercícios de análise na escola. Solicitadas a se expressarem sobre os exercícios de análise que fizeram acerca das situações de trabalho em sua escola a partir dos focos coletivamente escolhidos, a tendência das trabalhadoras nos primeiros diálogos desse dia foi de ocupar o lugar de relatoras e descritoras, porta-vozes das reivindicações alheias, sendo 
apresentados problemas elencados em termos de "O professor de educação física disse... [...] A professora da sala de leitura pediu...".

A primeira dupla do dia é formada por uma merendeira e uma professora. Apesar de apresentarem suas falas separadamente, o fato de se colocarem como um par que realizou os exercícios de análise na mesma escola já representa um começo na derrubada dos muros acima comentados.

A professora em questão explica que usou um questionário (elaborado por sua iniciativa, sem ter sido essa uma orientação da equipe) como instrumento para realizar o exercício na escola em que trabalha. Em seu trabalho interlocutivo, compartilha com o grupo presente os aspectos destacados pelo conjunto de professoras dessa escola e os comentários suscitados, a partir da resposta coletiva dada ao referido questionário. Momentos antes da mudança de estilo de fala que orienta a sequência 1, ela está respondendo ao grupo sobre a ocupação do espaço da escola (a organização e adequação em termos de localização de banheiro, presença de rampas etc.), bem como sobre as mudanças que a "inovação" governamental implementava nas escolas, introduzindo trabalhadores da empresa de serviços de limpeza urbana da cidade (Comlurb), no que tange à reorganização do trabalho coletivo. ${ }^{16}$ Sua fala é sucedida por uma série de intervenções dos participantes, comentando os efeitos dessa mudança na escola, com destaque dado ao vazio deixado pela ausência das antigas servidoras que atuavam também em ações coletivas (França \& Muniz, 2011), a fim de suprir a falta de funcionárias (ficar com a turma enquanto a professora se ausenta da sala, por exemplo), trabalhos que os funcionários da Comlurb não fazem.

A sequência 1 tem início ${ }^{17}$ quando, como em outras vezes, o pesquisador 1 passa a palavra, no caso a J. (merendeira, que a havia pedido, levantando mão), a fim de que possa ser ouvida pelas demais que falam ao mesmo tempo. Como característica da dinâmica interlocutiva nos encontros sobre o trabalho, os pesquisadores profissionais compartilham a coordenação do evento no sentido de abrir canais de expressão, sempre em função dos focos privilegiados para cada encontro. Mas isso não é uma regra. Temos registros de situações em que, espontaneamente, as participantes dispõem de instrumentos técnicos como do quadro e do giz, alternando com os outros pesquisadores o lugar de quem explica, demonstra e argumenta.

A sequência 1 tem duração total de 8 minutos e 24 segundos. Não foi toda reproduzida aqui por razão de espaço. Procedemos a recortes a partir de trechos selecionados como de interesse para o enquadre clínico. Os cortes poderão ser notados pelas interrupções nas sequências numéricas que introduzem cada turno de fala. ${ }^{18}$

\section{Sequência 1: auxiliar de merendeira, merendeira ou cozinheira? Merenda ou refeição?}

1 Pesq. 1: J. fala aí, J.

2 Merendeira 1: eu queria falar o seguinte gente, é:: que eu acho a maio- maioria das pessoas não tava no no: no:: no encontro de funcionários ${ }^{19}$

3 Irr: no [ ]

16 Tarefa que até então era efetuada por trabalhadoras do próprio coletivo de trabalho da escola, estas vistas como educadoras.

17 Já se passaram 1 hora, 22 minutos e 27 segundos de atividade dialógica desde o início do encontro.

18 Nos textos dos diálogos serão feitas as abreviações "Pesq." para profissional de pesquisa, "AP” para professora aposentada e "Irr." para indicar que não se chegou a reconhecer a voz de quem fala. $\mathrm{O}$ espaço entre colchetes "[ ]" diz respeito à duração da fala ininteligível e os dois pontos depois das vogais assinalam que elas foram prolongadas na fala. O sublinhado indica o que queremos destacar e as letras maiúsculas são um recurso utilizado para marcar um tom de voz mais alto ou mais expressivo usado pelo locutor. O lugar de registro da expressão linguística no enunciado visa indicar as relações de concomitância, complementaridade, disputa dos sentidos na fala. Será usada a letra "E" de enunciado para indicar o segmento em que o exemplo em destaque ocorre.

19 A merendeira faz referência ao encontro sindical do segmento de "funcionários", componente da estrutura organizacional do Sindicato, após sua unificação, aglutinando o conjunto de "profissionais de educação". 
4 Merendeira 1: é::

5 Irr: [ ]

6 Merendeira 1: a PP. deu uns uns formulário lá pra nós e no formulário tá escrito assim.. "auxiliar de merendeira", S. auxiliar de merendeira existia e tem duas pessoas ainda aposentadas que não morreram que o resto já morreu, tá?

7 Irr: [ ]

8 Merendeira 1: então tá lá, inativa, aposentada, duas. Então o que que a auxiliar de merendeira fazia? Ela cortava, era igual como se era restaurante. No restaurante é o chefe,

9 Pesq. 1: hum, hum

10 Merendeira1: são as merendeiras de cozinha e os auxiliares, elas que lava a panela, é o que corta a carne, então antigamente na prefeitura existia auxiliar de merendeira.

11 Merendeira 1: então hoje em dia, só tem a merendeira, e na escola que tem uma merendeira tem que ter outra- uma auxiliar, duas merendeiras e uma auxiliar, e aí não tem, então fica a merendeira fazendo tudo sozinha... então isso, a gente tem que procurar saber porque isso tá acabando conosco e a merendeira naquela época era merendeira porque servia leite, pão e biscoito.

Num primeiro momento, pode-se dizer que o objetivo procurado por M1 (merendeira 1) é chamar a atenção da audiência para o processo de precarização do trabalho de merendeira - do fazer merenda a cozinhar; a ampliação de suas tarefas não veio acompanhada da titulação pertinente, além do mais perdendo a auxiliar, pois, formalmente, as serventes não podem manipular alimentos - e o fato de esse processo estar afetando sua saúde ("então fica a merendeira fazendo tudo sozinha... então isso, a gente tem que procurar saber, porque isso tá acabando conosco" - E11). O trabalho de determinação do tema pode ser acompanhado através do recurso à argumentação. $\mathrm{O}$ argumento parte de uma informação obtida em um "encontro de funcionários", o qual tem presumidamente a finalidade de tratar de temas referentes aos interesses daqueles segmentos de trabalhadoras de escola (como "funcionárias", formalmente não são responsáveis por tarefas pedagógicas, embora o movimento de trabalhadoras de escola as entenda e defina como educadoras), sendo, portanto, relevante saber algo que tenha sido retirado de lá. Como operação discursiva, trata-se mesmo de um entimema, operação lógico-discursiva pela qual um locutor pode reforçar o efeito de sua argumentação sobre o interlocutor, não entrando explicitamente no detalhe, apresentando as premissas e conclusões como derivadas, provocando um efeito discursivo com base no uso do implícito (Amossy, 2006).

\begin{tabular}{|l|l|}
\hline Enunciado & Entimema \\
\hline $\begin{array}{l}\text { eu queria falar o seguinte gente, é:: que eu acho a maio- } \\
\text { maioria das pessoas não tava no no: no:: no encontro de } \\
\text { funcionários. }\end{array}$ & $\begin{array}{l}\text { As participantes da interlocução devem saber sobre o que se } \\
\text { passa nesse encontro, já que ele tem a finalidade de tratar } \\
\text { temas referentes aos interesses das trabalhadoras de escola. } \\
\text { Portanto, é relevante saber de algo que foi retirado de lá. }\end{array}$ \\
\hline
\end{tabular}

No referido encontro, M1 fica sabendo da existência, no passado (existência passível de prova já que documentado no formulário a que M1 faz menção), de uma categoria profissional de "auxiliar de merendeira" e é justamente essa informação que ela toma como o melhor argumento para provocar a reação das interlocutoras. Sua ação se funda na crença de que a maior parte das participantes desconhece esse fato (porém, não se podem descartar os efeitos da ironia). As operações discursivas realizadas na construção do discurso dão continuidade à atividade argumentativa voltada a produzir no interlocutor o efeito desejado: a imagem da precarização por que passa o trabalho de quem é categorizado como merendeira. O processo interlocutivo leva o interlocutor a tomar conhecimento de uma realidade passada a fim de 
confrontá-la à realidade presente. Tanto a referência ao documento escrito distribuído no encontro de funcionários como fonte da informação que descreve a realidade "passada" do trabalho de merendeira, quanto a referência que faz M1 à sua própria experiência, produzem o efeito de verdade dificilmente contestável (observe-se o trabalho de deslocamento de sistema de referência em E11: merendeira $\rightarrow$ a gente $\rightarrow$ [nós] $\rightarrow$ merendeira).

\begin{tabular}{|c|c|c|c|c|}
\hline \multicolumn{2}{|c|}{ Passado } & \multicolumn{2}{|c|}{ Presente } & \multirow{2}{*}{$\begin{array}{c}\text { Futuro } \\
\text { tá acabando conosco }\end{array}$} \\
\hline $\begin{array}{l}\text { no formulário tá } \\
\text { escrito:_ } \\
\text { auxiliar de merendeira }\end{array}$ & $\begin{array}{l}\text { O que que a auxiliar } \\
\text { de merendeira fazia? } \\
\text { Ela cortava }\end{array}$ & $\begin{array}{l}\text { era igual como se era } \\
\text { restaurante } \\
\text { No restaurante é o } \\
\text { chefe }\end{array}$ & $\begin{array}{l}\text { hoje em dia, só tem a } \\
\text { merendeira, }\end{array}$ & \\
\hline & & $\begin{array}{l}\text { são as merendeiras } \\
\text { de cozinha }\end{array}$ & & \\
\hline & & $\begin{array}{l}\text { e os auxiliares, elas } \\
\text { que lava a panela, é o } \\
\text { que corta a carne }\end{array}$ & & \\
\hline $\begin{array}{l}\text { a merendeira naquela } \\
\text { época era merendeira }\end{array}$ & $\begin{array}{l}\text { porque servia leite, } \\
\text { pão e biscoito }\end{array}$ & & $\begin{array}{l}\text { hoje nós somos } \\
\text { cozinheira e nós não } \\
\text { temos ajuda ... }\end{array}$ & $\begin{array}{l}\text { nós temos que ter } \\
\text { mais ajuda ainda do } \\
\text { que antigamente }\end{array}$ \\
\hline
\end{tabular}

As operações discursivas realizadas referem-se aos recursos expressivos usados para agir sobre o outro. Esses recursos se apoiam no fato de que a argumentação se constrói sobre pontos de acordo, premissas compartilhadas pela audiência e se desencadeiam tanto com base na razão quanto na emoção. A razão se dirige ao entendimento, corresponde ao logos e representa a base do trabalho com a linguagem de M1. Seu texto parte de um entimema que se completa em E26 (como se pode ver abaixo):

Merendeira fazia merenda

Tinha auxiliar

Cozinheira faz refeição... (Não tem? Como fica?)

Mesmo que a ação sobre o outro seja instrumentalizada sobre a convicção racional, a emoção desempenha um importante papel nesse agir. O pathos, ou seja, as emoções, desempenha em uma argumentação o efeito de colocar a audiência em certa disposição (Amossy, 2006). A sequência de atos de M1 que se desenvolve de E14 a E16-E18 a E20-E22 traz recursos expressivos que orientam para a presença da emoção no discurso. Além das suspensões no fio do discurso [...], ocorre mudança de tom de voz, e o recurso à primeira pessoa do singular: "eu". Ainda que breves, esses movimentos contrastam com o retorno às vias racionais, representadas pelo silogismo exteriorizado em 26.

11 Merendeira 1: então hoje em dia, só tem a merendeira, e na escola que tem uma merendeira tem que ter outra- uma auxiliar, duas merendeiras e uma auxiliar, e aí não tem, então fica a merendeira fazendo tudo sozinha... então isso, a gente tem que procurar saber porque isso tá acabando conosco e a merendeira naquela época era merendeira porque servia leite, pão e biscoito

12 Pesq. 1: $\quad$ era merenda mesmo.

$13 \mathrm{AP}: \quad$ preparava sanduíche 
14 Merendeira 1:

ajuda ...

$15 \mathrm{AP}:$ era merendeira, hoje nós somos cozinheira e nós não temos

[nem salário fixo]

16 Merendeira 1: entendeu? então-

17 AP: $\quad$ tem que brigar... a a:: auxiliar ela preparava, lavava o arroz, catava o feijão, descascava os legumes, cortava a carne

18 Merendeira 1: olha quando eu li eu fiquei... eu...

19 AP: aí você vê que tinha

20 Merendeira 1: eu fiquei...

21 AP:

22: Merendeira 1: tinha auxiliar de merendeira... [

23 Pesq. 1: andamos para trás

24 Irr: [ ]

25 Irr: [ ]

26: Merendeira 1: ... aposentadas, não, aposentada [ ] falava no papel que a PP. deu lá no encontro de funcionários, e nós não temos mais ajudas nós temos que batalhar pra isso, porque se nós somos merendeira se nós não somos merendeiras nós somos cozinheiras... nós temos que ter mais ajuda ainda do que antigamente

Neste ponto, não é a atividade argumentativa em si que constitui o centro de interesse da sequência, mas a dinâmica interlocutiva que se processa em termos da atividade dos outros participantes em relação ao trabalho sobre a linguagem. $\bigcirc$ movimento que nos interessa ressaltar tem início em E11-E12-E13-E14 e se estende ao longo do segmento abaixo:

38 Merendeira 2: mas a auxiliar. (várias vozes) a auxiliar ficava o que, não tinha-?

39 Merendeira 3: ela cortava o pão, botava manteiga

40 AP: ajudava, passava [manteiga] enquanto a outra fazia o leite o chocolate

41 Merendeira 3:

a merendeira fazia o leite e servia e aí a auxiliar lavava lavava as panelas lavava

45 Merendeira 3: cortava pão, passava manteiga [ ]

46: P: a cozinheira hoje

47: Irr:

tem auxiliar

48: P: prepara a comida e tem aquela que ajuda, descasca os legumes, cata feijão

É o momento quando as interlocutoras fazem da atividade de fala um instrumento diferente. Há transformações instrumentais que ocorrem quando a atividade deixa de ser dirigida aos pesquisadores profissionais e passa a outra que demonstra que as trabalhadoras não agem sozinhas, que existe uma ligação entre elas: a experiência-trabalho em comum (como "grupos homogêneos"), serve de apoio para os seus planos de ação (autônomos, com base no princípio da "não delegação") com base em sistemas de referência compartilhados. Ocorre um trabalho de E38 a E48 (iniciado em E12, E13 e E17, acima) de validação coletiva sobre as atividades de auxiliar de merendeira/merendeira/cozinheira. E depois entre E90 e E109 (abaixo) no sentido de trabalhar as relações dialógicas que implicam diferentes sistemas de referência, ao mesmo tempo, em retorno, sua ação auxilia na (re)construção dessa experiência.

90 Professora: $\quad$ eu não sei porque é minha experiência pessoal. Eu tenho 50 anos de idade não sou tão novinha estudei em escola da rede municipal no bairro onde eu 
moro e:: eu lembro que não era só uma merenda era refeição ${ }^{20}$ sim porque eu comia o tradicional macarrão com salsicha, polenta com carne-seca...

91 Irr: $\quad$ peixe

92 Professora: peixe, é

93 AP: mas era uma comida só

94 Professora: é, talvez não fosse tão elaborada

95 AP: isso era a chamada merenda

96 Professora: Ah!..

97 Merendeira3: também (várias vozes)

98 AP: era o angu com carne moída mas era um prato só.

99 Professora: hã, hã

100 Pesq1: a partir de um dado momento, no governo Brizola..[ ]

101 AP: Hoje você tem arroz feijão carne salada. Virou uma refeição

102 Professora: Isso. aí tá bom (várias vozes)

103 Merendeira1: na época era menas coisa e tinha uma estrutura. [E hoje em dia ]

104 Professora: Infelizmente hoje a gente carece mesmo de material humano

105 AP: A precarização está aumentando tanto que daqui a pouco

106 Merendeira1: [ ] ]

107 AP: $\quad$ a merendei- a zeladora ou a professora ou a diretora vai ter que

fazer tudo mas é::

108 Professora: mas é

109 AP: em vez de andar para frente está andando para trás (1.30.51)

O trabalho sobre a linguagem, no movimento histórico-cultural de sistemas de referência, torna-se um instrumento psicológico da ação. Há uma transformação que tem efeitos sobre o grupo. As demais merendeiras e uma trabalhadora já aposentada da escola (AP) passam a explicar o que era o trabalho da auxiliar com a preocupação de dizê-lo a uma merendeira mais nova, e isso afeta os instrumentos simbólicos. Na verdade, elas vão dar suporte ao trabalho linguístico de M1, mas constituindo o trabalho sobre o termo "auxiliar de merendeira" como um tema próprio (de E38 a E48). Esse trabalho se desenvolve a partir da contrapalavra que constrói a professora. $O$ trabalho interlocutivo sobre o tema prossegue, embalado agora de um modo que revela o entrecruzamento de sistemas de referência: do recurso às formas verbais (cortava, passava, fazia), o discurso passa ao sistema de referências da professora que orienta a definição do termo, não a partir das ações envolvidas na atividade de trabalho das merendeiras, mas a partir da sua experiência como aluna, que promove a seleção de substantivos que nomeiam o produto desse trabalho: "macarrão com salsicha, peixe...". $\bigcirc$ uso dos substantivos é coerente com essa mudança de ponto de vista. Contudo, o que é de interesse destacar é como essa mudança afeta e transforma o sistema de referência com o qual ela realiza o seu próprio tema, como se pode verificar em E92, E94, E96, E99 e E102.

20 Constata-se que, na época mencionada, havia diferentes "realidades". Em algumas delas, era servido apenas lanche e, eventualmente, sem qualquer garantia e sistematicidade, era servido o mencionado macarrão. Além disso, a cultura de classe média preponderante considerava que se devia trazer merenda de casa. Ir para aquela salinha da merenda era testemunhar pobreza. A comida eventual era um prato qualquer. Enfim, nem um terço dos alunos comia o que era servido na escola e nem sequer iam até o refeitório, sendo a carga de trabalho muito menor. 


\begin{tabular}{|c|c|c|c|c|}
\hline \multicolumn{5}{|c|}{ Encontro de sistemas de referências } \\
\hline $\begin{array}{l}\text { a merendeira naquela } \\
\text { época era merendeira }\end{array}$ & era merenda mesmo & $\begin{array}{l}\text { mas a auxiliar. (várias } \\
\text { vozes) a auxiliar ficava } \\
\text { o que }\end{array}$ & $\rightarrow$ & era uma comida só \\
\hline $\begin{array}{l}\text { porque servia leite, } \\
\text { pão e biscoito }\end{array}$ & preparava sanduíche & $\begin{array}{l}\text { ela cortava o pão, } \\
\text { botava manteiga } \\
\text { passava [manteiga] } \\
\text { enquanto a outra fazia } \\
\text { o leite o chocolate } \\
\text { a merendeira fazia o } \\
\text { leite e servia e aí a } \\
\text { auxiliar lavava lavava } \\
\text { as panelas lavava } \\
\text { cortava pão, passava } \\
\text { manteiga }\end{array}$ & $\begin{array}{l}\text { e tem aquela que } \\
\text { ajuda, descasca os } \\
\text { legumes, cata feijão }\end{array}$ & $\begin{array}{l}\text { macarrão com } \\
\text { salsicha, polenta com } \\
\text { carne-seca... (E90) } \\
\text { peixe (E91, E92) } \\
\begin{array}{l}\text { angu com carne } \\
\text { moída (E98) }\end{array}\end{array}$ \\
\hline
\end{tabular}

A sequência 1 foi escolhida justamente por representar um fecundo exemplo de uma atividade linguageira que, tendo-se iniciado como uma atividade em que uma merendeira opera recursos expressivos a fim de guiar a "audiência" (tanto as trabalhadoras interlocutoras presentes, como também a entidade Fiocruz ${ }^{21}$ o sindicato ali representado) a concluir sobre a legitimidade de sua reivindicação:

\section{porque se nós somos merendeira se nós não somos merendeiras nós somos cozinheiras... nós temos que ter mais ajuda ainda do que antigamente.}

Ao mesmo tempo e no interior desse enquadre, a sequência se transforma em um trabalho coletivo sobre a linguagem de construção de significado em diferentes sistemas de referência: do significado de "auxiliar de merendeira" em termos de sua atividade, bem como do seu produto: a merenda.

No contexto do Programa de Formação, a sequência 1 polariza o encontro de conceitos e sistemas de referência: no trabalho de construção do tema com recurso à argumentação, M1 se confronta com as outras para quem a (re)construção do passado, núcleo de seu argumento, passa por um movimento de adesão e de questionamento (sobre a atividade da auxiliar de merendeira e em que consistia a chamada "merenda") que passa, justamente, a ser a força motriz do desenvolvimento da atividade argumentativa de M1, e depois do coletivo.

\section{Sequência 2: trabalho prescrito versus o "real da atividade". O que é ser auxiliar de creche?}

Não vamos nos estender nas análises da sequência 2, mas optamos por trazê-la a fim de mostrar outra dinâmica interlocutiva, outro trabalho com e sobre a linguagem que atesta a plasticidade do dispositivo clínico engendrado nos encontros sobre o trabalho. Na sequência que se segue, chama a atenção o embate dialógico entre dois auxiliares de creche sobre os contornos de sua atividade, com destaque para as reações em E7, E11 e E13:

1 Pesq. 3: Deixa eu fazer uma... em sala de aula você só aprende aquele trabalho, né? E é um trabalho... que trabalho é esse? (várias vozes)

21 A Fiocruz, enquanto uma das instituições parceiras do Programa de Formação, é reconhecida como grande referência na produção científica em saúde. 
2 Auxiliar de creche 1: teoricamente é de forma mais administrativa não é um trabalho pedagógico nem algo relacionado a isso. As funções do auxiliar de creche é o quê? Cuidar pra ver se criança tá limpa, dar banho, limpar bumbum, trocar as fraldas, é isso!

3 Auxiliar de creche 2: brincar com ele.

4 Auxiliar de creche 1: legalmente falando ele teria que fazer isso. A função dele é essa, só que ele não faz isso. Ele faz a mais. Então quem entra dentro de uma sala suja como ele, teoricamente ele vai fazer o trabalho de uma maneira bem. Porque ele não vai entrar na sala sozinho, ele vai ter as pessoas com ele pra auxiliar ali. E essas pessoas que já são podem auxiliá-lo no trabalho tranquilo. "Olha aí a criança e tal!" Teoricamente ele pode fazer isso. Ele tem o poder de entrar na sala e fazer o trabalho.

6 Pesq. 2: Eu tava querendo também falar.

7 Auxiliar de creche 3: eu já tô tendo taquicardia! (risos) Não, assim me causa espanto ele falar que é um trabalho simples que pra mim não é.

8 Auxiliar de creche 2: não é não!

9 Auxiliar de creche 3: não é, sabe.

10 Auxiliar de creche 2: criança doente.

11 Auxiliar de creche 3: eu já trabalho há um tempo e eu acho que o que o W. está se referindo a só o que está no edital, ao que o cargo...

12 Pesq. 3:

ao prescrito.

13 Auxiliar de creche 3: $\quad$ prescreve, isso. Mas não à situação real. Porque eu não consigo entender muito simples porque não é só o cuidar. $\mathrm{O}$ dar o banho. Aquele dar banho também tem um cunho pedagógico. $\mathrm{O}$ dar a comida também tem um cunho pedagógico. E assim, em todos os momentos a gente se preocupa em direcionar qualquer atividade que seja a nossa atividade dentro da creche pra um objetivo. A gente tem um objetivo. Mesmo quando você tá dando banho, você tá dando comida que parece pra algumas pessoas coisas simples. Por exemplo, digamos assim não seja ignorante um auxiliar de serviços gerais que não tenha capacidade de fazer isso na minha creche. Inclusive teve uma que era auxiliar de serviços gerais e que atualmente tá como recreadora e é muito capaz. Mas eu percebo assim, é... como é que uma pessoa que não conhece o desenvolvimento da criança, por exemplo não tenha a percepção alguém aqui comentou "a criança não tá comendo porque mudou de professora". Então como é que vai ser a atuação dessa pessoa que não tem esse olhar diferenciado? Se acha que aquilo ali é só um corpo que está sendo cuidado. E a cabeça fica aonde? E a mente? A gente tem que trabalhar o todo, o ser humano. Então assim, me dá até taquicardia quando eu escuto ele falando que é simples, não é. (várias vozes)

14 Auxiliar de creche 1: Quando eu digo que é simples se eu tiro todas as questões envolvidas assim de coisa... é simples no sentido de há limitativos, entendeu? É claro que existem essas peculiaridades de que é um trabalho complexo. Acho que também não fui muito feliz quando falei que era simples. (várias vozes)

15 Auxiliar de creche 3: Nem o trabalho administrativo era simples. (várias vozes)

Se E1 e E2 fossem trocas constituídas por um instrumento como a entrevista, por exemplo, seria possível dizer que AC1 vê o trabalho que faz como um trabalho extremamente simples, sem nenhuma demanda de competência pedagógica. No entanto, o dispositivo dialógico permite compreender o lugar de sua intervenção nos processos interlocutivos que vinham se desenvolvendo no programa. Tanto em E2 como em E4, os enunciados do AC1 não estão respondendo apenas à pergunta do pesquisador profissional. Eles fazem parte do grande diálogo que se instaurou na versão de 2008 do Programa de Formação por intermédio de discursos que traduzem uma das principais ameaças às trabalhadoras de escola no Rio de Janeiro: a precarização do trabalho com a falta de efetivo, por um lado; e, por outro, as reorganizações coletivas que incluem a participação da categoria de auxiliar de serviços gerais 
nas atividades de professoras, merendeiras e auxiliares de creche e as consequências que isso gera (agravadas pela substituição dessa categoria por funcionários da Comlurb).

Os recursos apreciativos operados por AC1 em E2 tiram o brilho e a complexidade de seu trabalho como parte de uma ação voltada a justificar por que esse auxiliar de creche aceita compartilhar suas atividades com profissionais de outra área. Os traços desse grande diálogo podem ser observados em E4 (trecho em negrito).

Com emoção (risos, escolha lexical e tom de voz), AC3 intervém para expressar a não coincidência entre os sistemas de referência que lhe permitem a construção linguística de sua experiência. Por meio desse trabalho, ela não só constrói seu modo de ver o que é ser auxiliar de creche como também interage com a questão implicada na fala de AC1 (E13 "Por exemplo, digamos assim não seja ignorante um auxiliar de serviços gerais que não tenha capacidade de fazer isso na minha creche...”).

Outro aspecto que não pode ser deixado de lado é o papel instrumental que exerce o conceito de "prescrito", trazido à tona pelo trabalho conjunto (quase simultâneo) - entre o pesquisador profissional e MC3 - sobre o porquê da simplificação da atividade operada por MC1. Na verdade, é a análise que lança mão desse conceito que permite o desenvolver do diálogo e da reflexão que começa a se operar em E14. E isso consiste em um dos eixos instrumentais e desenvolvimentais com que opera o dispositivo CAPP.

\section{Considerações finais}

As pesquisas realizadas em clínica da atividade (Henry \& Bournel-Bosson, 2008; Kolstuski, 2004; Litim, 2006; Osório, 2008; Scheller, 2003; Teixeira \& Barros, 2009), bem como por outras clínicas do trabalho (Borges, 2008; Neves, Brito \& Athayde, 2003; Muniz, 2000; Souza, 2009) trouxeram frutuosas provas de que a análise das ações realizadas com e sobre a linguagem é fundamental para o estudo dos objetos próprios à psicologia, principalmente com respeito ao trabalho de construção de temas e ao desenvolvimento de relações dialógicas.

A linguística que pode fornecer os meios para essa análise possui estatuto de pesquisa fundamental de campo. Assim como na clínica da atividade, ou em outras vertentes da Psicologia de orientação vygotskyniana, só se pode estudar o desenvolvimento, provocando-o. Para esse ramo da linguística e de abordagem clínica do trabalho, produzir conhecimento sobre linguagem só é possível de um modo que seja também colocando-a em movimento, provocando o desenvolvimento de relações dialógicas.

Assumimos a posição de que os chamados "objetos do discurso" não preexistem naturalmente à atividade cognitiva e interativa dos sujeitos, mas são concebidos como produtos histórico-culturais dessa atividade. A aprendizagem tem a função de impulsionar os "vários processos internos de desenvolvimento, que são capazes de operar quando [...] se interage com pessoas em seu ambiente e quando em cooperação com seus companheiros" (Vygostsky, 1991, p. 101). A clínica exercida no Programa de Formação (como indica a designação) é ação e não apenas quadro, no sentido de que quem estabelece as relações dialógicas no fio do discurso são aqueles que tecem os laços da cultura histórica compartilhada nas escolas, operando sistemas de referências. $O$ trabalho de construção de sentido nos encontros sobre o trabalho diz respeito a essa produção histórica e social de sistemas de referências, em relação aos quais os recursos expressivos se tornam significativos para as trabalhadoras de escola. Esse processo é fonte e recurso para as transformações do trabalho na escola, conforme relato das protagonistas do Programa (Silva, 2003; Reis, 2009). 


\section{Referências}

Amossy, R. (2006). L'argumentation dans le discours. Paris: Armand Colin.

Bakhtin, M. (V. N. Volochínov). (1929/1988) Marxismo e filosofia da linguagem (Michel Lahud e Yara Frateschi Vieira, trad., 4ae ed.). São Paulo: Hucitec.

Bakhtin, M. (1929/2003). Pour une philosophie de l'act. Lausanne: L'age d'Homme.

Bakhtin, M. (1997). Estética da criação verbal. São Paulo: Martins Fontes.

Brito, J., Athayde, M. \& Neves, M. Y. (2003). Caderno de métodos e procedimentos: programa de formação em saúde, gênero e trabalho nas escolas. João Pessoa: UFPB.

Brito, J. \& Athayde, M. (2003). Trabalho, educação e saúde: o ponto de vista enigmático da atividade. Trabalho, Educação e Saúde, 1 (2), 63-89.

Borges, E. (2008). O rei está nu: tramas e urdiduras por uma gestão coletiva do trabalho. Tese de Doutorado, Programa de Pós-Graduação em Psicologia Social, Universidade do Estado do Rio de Janeiro, Rio de Janeiro.

Cavalcanti, M. \& Moita-Lopes, L. P. (1991). Implementação de pesquisa na sala de aula de línguas no contexto brasileiro. Trabalhos em Lingüística Aplicada, 17, 133-144.

Celani, M. A. (1992). Afinal o que é Lingüística Aplicada? In M. S. Z. Paschoial \& M. A. Celani, (Orgs.), Linguística Aplicada: da aplicação da linguística à linguística transdisciplinar. São Paulo: Educ.

Clot, Y. (2010). Trabalho e poder de agir. Belo horizonte: Fabrefactum.

Clot, Y. (2006). Clínica do trabalho e clínica da atividade. Nouvelle Revue de Psychologie, 1, 165-177.

Clot, Y. \& Faïta, D. (2000). Genres et styles en analyse du travail. Concepts et méthodes. Travailler. Revue Internationale de Psychopathologie et de Psychodynamique du Travail, 4, 7-42.

Daher, D. C. \& Sant'Anna, V. L. A. (2010). Formação e exercício profissional de professor de língua espanhola: revendo conceitos e percursos. In C. S. de Barros e E. G. M. da Costa (Orgs.), Espanhol: ensino médio (Coleção Explorando o ensino, v. 16). Brasília: Ministério da Educação, Secretaria da Educação Básica.

Dejours, C. (2004). O trabalho como enigma. In S. Lancman \& L. I. Szelwar (Orgs.), Christophe Dejours: da psicopatologia à psicodinâmica do trabalho (pp.127-139). Rio de Janeiro: Fiocruz.

Di Fanti, M.G. (2004). Discurso, trabalho e dialogismo. Tese de Doutorado, Programa de Pós-Graduação em Linguística Aplicada, Pontifícia Universidade Católica de São Paulo, São Paulo.

Durrive, L. (2010). Pistas para o ergoformador animar os encontros sobre o trabalho. In Y. Schwartz \& L. Durrive (Orgs.), Trabalho e ergologia: conversas sobre atividade humana (pp. 309-318). Niterói: Eduff.

Faïta, D. (1989). Mondes du travail et pratiques langagières. Parole(s) ouvrière(s). Langage, 93, 110-128

Faïta, D. (1992). Le travail du controleur SNCF: deplacement discursif et mouvements de l'interaction. Cahier Langage et Travail, 4, 25-34.

Faïta, D. (1996). Le questionnement parmis les ressources de l'analyse du travail: comment créer les conditions du dialogue entre l'operateur et l'intervenant? Cahier de Linguistique Sociale, 28-29, 291-300.

Faïta, D. (2005). Análise dialógica da atividade profissional. Rio de Janeiro: Imprinta.

Faraco, C. A. (2001). Pesquisa aplicada em linguagem: alguns desafios para o novo milênio. Revista DELTA, 17, Especial, 1-9.

Faraco, C. A. (2003). Linguagem Eु diálogo: as ideias linguísticas do círculo de Bakhtin. Curitiba: Criar Edições.

Faverge, J-M., Leplat, J. \& Guiguet, B. (1958). L'adaptation de la machine à l’homme. Paris: PUF.

Feitosa, V. C. R. (1996). Os escritos e o trabalho: um ensaio de ergonomia. Tese de Doutorado, COPPE, Universidade Federal do Rio de Janeiro, Rio de Janeiro.

Figueiredo, M. \& Athayde, M. (2004). Coletivos de trabalho e componentes subjetivos da confiabilidade em sistemas sociotécnicos complexos: considerações a partir da situação de trabalho em mergulho profundo na Bacia de Campos?/RJ. In M. Figueiredo, M. Athayde, J. Brito \& D. Alvarez (Orgs.), Labirintos do trabalho: interrogações e olhares sobre o trabalho vivo (pp. 241-275). Rio de Janeiro: DP\&A.

França, M. B. (2007). Uma comunidade dialógica de pesquisa: atividade e discurso em guichê hospitalar. São Paulo: Educ.

França, M. B. \& Muniz, H. P. (2011). As entidades coletivas relativamente pertinentes e o debate de normas e valores: uma perspectiva ergológica para a gestão dos serviços de saúde pública. Trabalho, Educação e Saúde, 9 (1), 201-222. 
Franchi, C. (1977). Linguagem: atividade constitutiva. Almanaque - Caderno de Literatura e Ensaios, 5, 9-27.

François, F. (1998). Le discours et ses entours: essai sur l'interprétation. Paris: L'Harmattan.

Freire, P. (1987). Pedagogia do oprimido (17ª ed.). Rio de Janeiro: Paz e Terra.

Freyre, G. (2006). Casa-grande Eु senzala: formação da família brasileira sob o regime de economia patriarcal (51ª ed. rev.). São Paulo: Global.

Frigoto, G. (2001). A produtividade da escola improdutiva: um reexame das relações entre educação e estrutura econômicosocial capitalista (6 $6^{\underline{a}}$ ed.). São Paulo: Cortez.

Geraldi, J. W. (2003). Portos de passagem. São Paulo: Martins Fontes.

Harrison, K. M. P. (2006). Processo de construção de um coletivo de trabalho bilíngue. Tese de Doutorado, Programa de Pós-Graduação em Linguística Aplicada, Pontifícia Universidade Católica de São Paulo, São Paulo.

Guérin, F., Laville, A., Daniellou, F., Duraffourg, J. \& Kerguelen, A. (2001). Compreender o trabalho para transformálo: a prática da ergonomia. São Paulo: Edgard Blücher.

Henry, M. \& Bournel-Bosson, M. (2008). La vie des mots en analyse du travail. Activités, 5 (2), 25-38.

Kostulski, K. (2004). Développement de la pensée et du rapport à l'autre dans une interlocution: “est-ce que c'est un endroit pour poser un paquet de contre-rails?" Cahiers de Linguistique Française, 26, 113-131.

Lacomblez, M. (1995). L'analyse ergonomique du travail et la formation professionelle. Education Permanente, 124, 81-88.

Lima, A. P. de (2010). Visitas técnicas: interação escola-empresa. Curitiba: CRV.

Litim, M. (2006). Les histoires de travail: un instrument du developpement du métier et de l'activité professionnelle: une analyse de l'activité soignante en gérontologie. Tese de Doutorado, Laboratoire de Psychologie du Travail, Conservatoire National des Arts et Metiers, Paris, França.

Luria, A. R. (1987). Pensamento e linguagem. Porto Alegre: Artes Médicas.

Machado, A. R. (Org.) (2004). O ensino como trabalho: uma abordagem discursiva. Londrina: Eduel.

Moita Lopes, L. P. (1996). Oficina de lingüística aplicada. Campinas: Mercado das Letras.

Moita Lopes, L. P. (1995). Transdisciplinaridade em lingüística aplicada? [mimeografado]

Neves, M. Y., Muniz, H., Silva, E., Costa, J., Brito, J. \& Athayde, M. (2007). Comunidade ampliada de pesquisa: pesquisadores e trabalhadores/as de escolas públicas colocam seus saberes em sinergia na busca da promoção da saúde a partir dos locais de trabalho. In S. B. Vieira \& E. Krutzen (Orgs.), Psicologia social, clínica e saúde mental (pp. 448-474). João Pessoa: Editora da UFPB.

Nunes, B. (2000). Merendeiras e serventes em situação de readaptação e o sentido do trabalho. Dissertação de Mestrado, Programa de Pós-graduação em Saúde Pública, Escola Nacional de Saúde Pública, Fiocruz, Rio de Janeiro.

Oddone, I., Re, A. \& Briante, G. (1977/1981). Redécouvrir l'expérience ouvrière: vers une autre Psychologie du Travail. Paris: Editions Sociales.

Ombrendane \& Faverge (1955). L'analyse du travail. Paris: PUF.

Osorio, C. (2011). A fotografia como uma marca do trabalho: um método que convoca o protagonismo do trabalhador na invenção de mundos. In A. V. Zanella \& J. Tittoni. (Orgs.), Imagens no pesquisar: experimentações (pp. 211-226). Porto Alegre: Dom Quixote.

Papegnies, S. (2006). Le geste gustatif comme instrument. Le changement d'une technique culinaire dans une cuisine municipale. Mémoire de Master Recherche, Conservatoire National des Arts et Metiers, Paris, França.

Rajagopalan, K. (2003). Sobre a dimensão ética das teorias linguísticas. In K. Rajagopalan (Org.), Por uma linguística crítica (pp. 49-56). São Paulo: Parábola.

Reis, K. (2009). A Aventura da mudança: sobre a diversidade de formas de intervir no trabalho para se promover saúde. Tese de Doutorado, Programa de Pós-Graduação da Escola Nacional de Saúde Pública, Fundação Oswaldo Cruz, Rio de Janeiro.

Sant'anna, V. L. de A. (2004). Mercosul em notícia: uma abordagem discursiva do mundo do trabalho. São Paulo: Educ.

Santos, G. A. dos. (1994). Ensino-aprendizagem de leitura em aulas de inglês na escola pública: um enfoque sóciointeracional. Dissertação de Mestrado, Programa de Pós-Graduação em Letras Anglo-Germânicas, Faculdade de Letras, Universidade Federal do Rio de Janeiro, Rio de Janeiro. 
Scheller, L. (2003). Élaborer l'expérience de travail: activité dialogique et référentielle dans la méthode des instructions au sosie. Tese de Doutorado, Laboratoire de Psychologie du Travail, Conservatoire National des Arts et Metiers, Paris, França.

Schwartz, Y. (2000). Le paradigme ergologique ou un métier de Philosophe. Toulouse: Octarès.

Schwartz, Y. (2004). Trabalho e gestão: níveis, critérios, instâncias. In M. Figueiredo, M. Athayde, J. Brito \& D. Alvarez (Orgs.), Labirintos do trabalho: interrogações e olhares sobre o trabalho vivo (pp. 23-33). Rio de Janeiro: DP\&A.

Schwartz, Y. (2010). O homem, o mercado e a cidade. In Y. Schwartz \& L. Durrive (Orgs.), Trabalho e ergologia: conversas sobre atividade humana (pp. 247-273). Niterói: Eduff.

Silva, E. F. (2003). Trabalhadores de escola e construção de uma "comunidade ampliada de pesquisa": a busca da promoção de saúde a partir dos locais de trabalho. Tese de Doutorado, Programa de Pós-Graduação da Escola Nacional de Saúde pública, Fundação Oswaldo Cruz, Rio de Janeiro.

Silva, D. N. (2010). Pragmática da violência. Tese de Doutorado. Programa de Pós-Graduação em Estudos da Linguagem, Universidade de Campinas, Campinas.

Silva, E., Brito, J., Neves, M. Y. \& Athayde, M. (2009). A Promoção da Saúde a partir das situações de trabalho: considerações referenciadas em uma experiência com trabalhadores de escolas públicas. Interface Comunicação Saúde Educação, 13 (30), 367-379.

Souza, W. F. (2009) Gestão em saúde, uma perspectiva ergológica: com quantos gestos se faz uma gestão. Tese de Doutorado, Programa de Pós-graduação em Psicologia Social, Universidade do Estado do Rio de Janeiro, Rio de Janeiro.

Souza e Silva. M. C. P. (2002). A dimensão linguageira em situações de trabalho. In M. C. P. Souza e Silva \& D. Faïta (Orgs.), Linguagem e trabalho: construção de objetos teóricos no Brasil e na França (pp. 61-76). São Paulo: Cortez.

Teiger, C. \& Lacomblez, M. (2007). Ergonomia, formações e transformações. In P. Falzon (Org.), Ergonomia (pp. 587-602). São Paulo: Edgard Blücher.

Teiger, C. \& Lacomblez, M. (Orgs.) (2013). (Se) Former pour transformer le travail: dynamiques de constructions d'une analyse critique du travail. Québec/Bruxelas: PUL/ETUI.

Teiger, C. \& Daniellou, F. (1987). Formation à l'analyse de l'activité et rapport au travail. In C. Dejours (Org.), Plaisir et souffrance dans le travail (pp. 77-94). Paris: AOCIP/CNRS.

Teiger, C. \& Laville, A. (1991). L'aprentissage de l'analyse ergonomique du travail, outil d'une formation pour l'action. Travail et Emploi, 47, 53-62.

Teixeira, D.V. \& Barros, M.E.B (2009). Clínica da atividade e cartografia: construindo metodologias de análise do trabalho. Psicologia e Sociedade, 21 (1), 81-90.

Vieira, M. (2002). A atividade, o discurso e a clínica: uma análise dialógica do trabalho médico. Tese de Doutorado, Programa de Pós-Graduação em Linguística Aplicada, Pontifícia Universidade Católica de São Paulo, São Paulo.

Vygotsky, L. S. (1991). A formação social da mente. São Paulo: Martins Fontes.

\section{Endereços para correspondência}

mbfranca@unirio.br, athayde.milton@gmail.com, heldermuniz@uol.com.br, myale@uol.com.br, jussaradebrito@gmail.com 